\title{
GATED COMMUNITIES: AN ERA FASHION IN A COLLISION COURSE IN THE NEW CAIRO SETTLEMENT, EGYPT
}

\author{
Ahmed A. A. Shetawy \\ Department of Planning and Urban Design Faculty of Engineering - Ain Shams University
}

\begin{abstract}
Throughout history, urban planning practice has always been shaped by powerful ideas controlled by class interests. "Gated communities", which are becoming an increasingly distinctive feature in contemporary cities worldwide, is one such idea. It has the ability to influence existing urban rich and poor, social and economic policies and plans, urban governance and physical planning decision-making at both national and local levels. While some scholars and practitioners defend the idea for being the core urban development engine without which cities worldwide, especially in Europe and the USA, should have deteriorated dramatically after WWII; others argue their destructive impact on the long-term sustainability of cities.
\end{abstract}

This paper poses to shed light on two interlocking concerns: first, to analyze and document the impact of gated communities on urban planning development and city management. Secondly, to explore the validity of such impact in the case of the New Cairo Settlement, Egypt.

KEYWORDS: Gated Communities, Urban Enclaves, Social Exclusion, New Cairo Settlement, Egypt

\section{INTRODUCTION}

"Gated communities are closed urban residential settlements voluntarily occupied by a homogeneous social group, where public space has been privatized by restricting access through the implementation of security devices. (...) their houses are of high quality and have services and amenities that can be used only by their residents (...) they have a private body governing and enforcing internal rules concerning behavior and construction" [1:9]

With specific reference to the above definition, there has been an explosion of gated communities all over the world since the end of WWII. Examples from countries around the globe show the magnitude of such explosion. In the United States of America, for example, there were more than 20,000 gated communities, with $3,000,000$ residential units in 1997 and more than 7,000,000 households living in walled communities in 2001 [2]. In England, more than a thousand gated communities housing 100,000 inhabitants are reported in 2003 [3]. Additionally, since the mid 1990s, an unprecedented increase of gated communities' development in Russia is well documented [4].

In the greater Buenos Aires region, Argentine, there are more than 11 million gated communities' inhabitants [5]. Gated communities are also a rapidly growing urban phenomenon in South Africa since the mid 1990s. There are more than 360 road closures related to gated communities activities in one substructure of the greater Johannesburg Metropolitan Council [6]. Moreover, although walls are not a new phenomenon in China, wealthy gated communities "are particularly novel in the Chinese context because income differences have only really been conspicuously revealed in spatial patterns since the housing market was created in the 1990s" [7]. Additionally, case study research in Portugal, Spain Turkey, and Indonesia confirm the magnitude of such urban phenomena growth during the past 20 years [1] [5].

Furthermore, the number of gated communities has also been on the rise in countries all over the Middle East Region (e.g. Saudi Arabia, Egypt, Lebanon, Qatar, Kuwait, Bahrain, Syria) since the early 1970s parallel to the influx of foreign manpower to the region and the oil boom. Leading the pace in the region, Saudi Arabia has the largest number of gated communities' inhabitants in the region with over one third of its population (more than 20 million inhabitants) living in gated communities [8] [9] [10] [11].

Consequently, scholars from various academic disciplines and practitioners all over the World are particularly interested in analyzing the reasons behind, on the one hand, the growth of gated communities around the globe and, on the other hand, the effect of such growth on all dimensions of city and urban 
development. Over the following section, a brief documentation to the concerned literature and the commonly key evaluation indicators to such effect are presented.

\section{GATED COMMUNITIES AND CITY DEVELOPMENT: EVALUATION INDICATORS}

\author{
"Gated and walled cities are as \\ old as city buildings itself"
}

Given the magnitude of growth of gated communities all over the globe, presented in the latter section, numerous methodologies and frameworks are constructed to evaluate the effect it has on all dimensions of city and urban development. Some of which focus on the impact of gated communities on property value and city economy [13] [14], while others on governance and city management [15] [16] [17] [18] [19]. Another group focuses on the security and life style dimension [20] [21] [22], while others on the built environment and city infrastructure [23] [24] and finally those on the social aspect of city development [25] [26] [27].

After an extensive literature review on the subject of gated communities, it is evident that practitioners and academics commonly agree that the peculiarity of gated communities, through history, rests on four elements: closure and privatization, security devices and amenities, private government and code of governance, and lifestyle and class homogeneity.

Consequently, given the aim to evaluate the impact of gated communities on the New Cairo development with specific reference to the different perceptions of the involved study population, this paper focuses on five easy-to-investigate indicators, reflecting the four underpinning elements of gated communities' development - the very same evaluation indicators adopted by many academics and practitioners in evaluating the gated communities phenomenon within different contexts. The five key indicators are: sense of community (i.e. social cohesion and exclusion), safety and security, urban planning, urban governance and management, and economic implications (i.e. the real estate value) [11] [16] [24] [28].

\section{METHODOLOGY AND METHODS}

The New Cairo Settlement (NCS), also known as AlQahira al-Gadida, is a new settlement built in the desert to the east of the capital, Cairo, as shown in figure (1). Ever since going the NCS in the mid 1990s to visit a friend who decided to move place of residence and later on when becoming a resident myself, I had the feeling that what I see is a 'mirage' of a deeply 'wellcamouflaged' conflicts. I can see parallel communities and social classes leading different lives and constituting multiple parallel cities within the very time and space edge. Nevertheless, since deciding to explore what I feel and sense, as a researcher, I have distanced myself from the findings of this paper seeking a 'zero-biased' research.

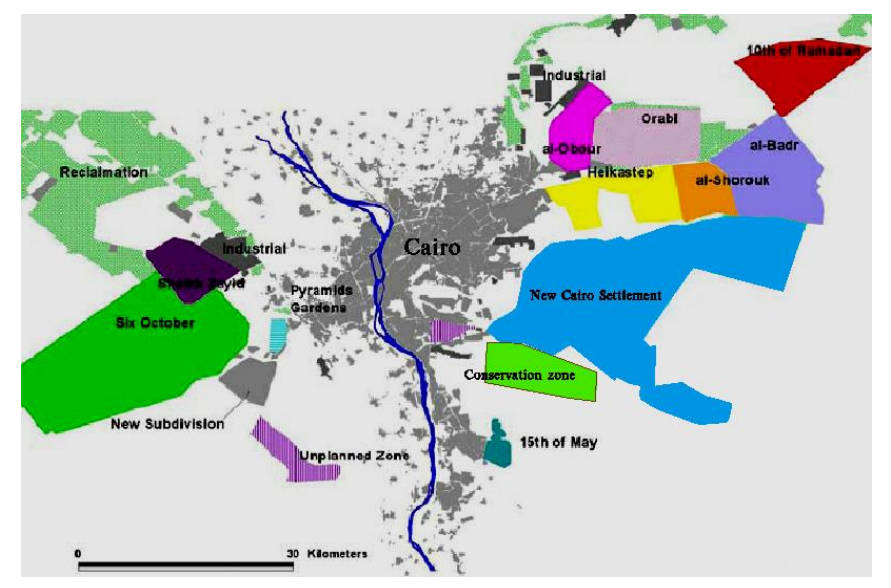

Figure (1) Location of the New Cairo Settlement

(NCS)

The study population is divided into five distinct groups: Government officials (i.e. New Urban Communities Authority (NUCA), New Cairo Development Authority (NCDA)), academic, urban planning consultants and practitioners, and residents of all income class residents (i.e. residents and managers of gated communities, highincome, middle-income, and low-income). The research adopts the classification of the Ministry of Housing, Utilities and New Urban communities regarding the different residential classes with specific reference to residence area. Semi-structured interviews were used to collect primary qualitative data selected through different sampling techniques as shown in table (1).

Semi-structured interviews were judged more appropriate than structured interviews given the nature of data required to be collected. The fieldwork focuses on Arabella gated community and its adjacent residential areas due to resources limitations (i.e. time and funding). The reasons are its manageable size and direct visual and physical contact with adjacent poor, middle and highincome residential areas, as seen in figure (2). Briefly, 47 interviewees of all groups were interviewed over a total period of two months (July - august 2009 - 10). The research has also made use of several secondary data sources, mainly documentation and archival records, while seeking data triangulation to confirm the validity and reliability of both primary and secondary data. 


\begin{tabular}{|c|c|c|c|}
\hline \multicolumn{2}{|c|}{ Study Population } & \multirow{3}{*}{$\frac{\text { Methods }}{\sum^{\infty}}$} & \multirow{3}{*}{$\begin{array}{c}\text { Sampling Technique } \\
\text { Purposeful then snow-balling }\end{array}$} \\
\hline \multirow{2}{*}{ Government Officials } & NUCA & & \\
\hline & NCDA & & \\
\hline Academics & ------------- & \multirow{6}{*}{ : } & Purposeful then snow-balling \\
\hline $\begin{array}{c}\text { Urban Planning } \\
\text { Consultants } \\
\end{array}$ & ----------- & & Purposeful \\
\hline \multirow{4}{*}{ Residents } & $\begin{array}{l}\mathrm{GC} \text { residents and } \\
\text { managers }\end{array}$ & & \multirow{4}{*}{$\begin{array}{l}\text { Purposeful / Stratified random } \\
\text { sampling then snow-balling }\end{array}$} \\
\hline & High-income & & \\
\hline & Middle-income & & \\
\hline & Low-income & & \\
\hline
\end{tabular}

Table (1) Study population, methods and sampling techniques

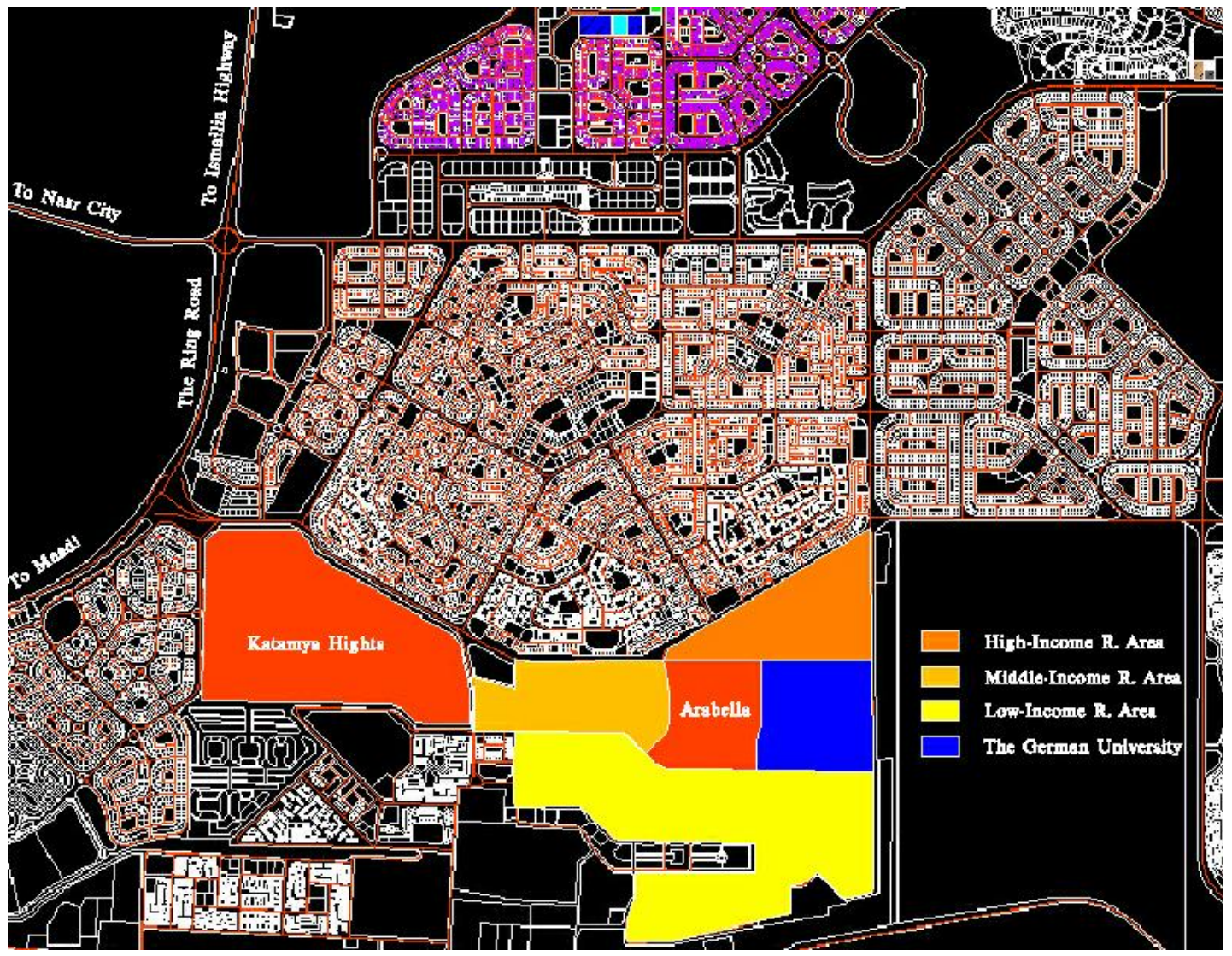

Figure (2) Location of Arabella Gated Community and surrounding residential areas

\section{THE NEW CAIRO SETTLEMENT (EGYPT): UNDERSTANDING THE PACE}

One cannot comprehend the development of the New Cairo Settlement (NCS) without seriously understanding the shift in the Egyptian political economy since 1952 when Egypt was announced a republic. It is also almost impossible without recognising the changing role of the state, public sector and private sector in urban development policy formulation and implementation since April 1974 when the new map of Egypt was delivered to the Egyptian Parliament by President Sadat, the very core upon which all successive urban development planning policies were formulated till this very date [29] [30] [31] [32] [33]. 


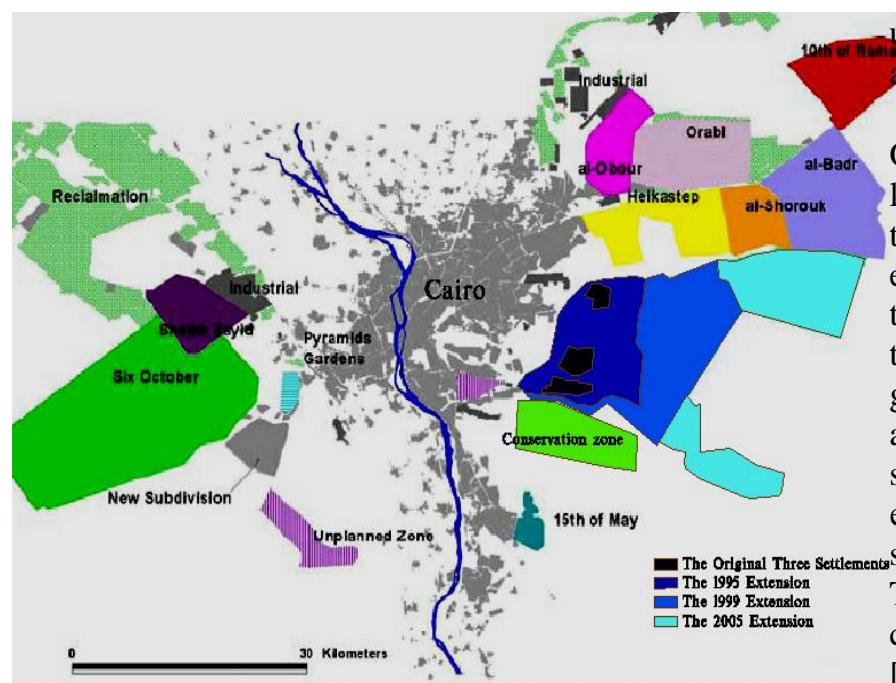

grading projects, and providing rural area with water dectricity supply.

On the other hand, the private sector activities was limited to the provision of the much needed investment to cover the gap between demand and supply in all economic fields (e.g. employment and housing) while the required incentives, regulations and laws to create the stable environment for such investment would be guaranteed and controlled by the state. Consequently, the aims of urban development policy at the time were to seek improvement and management of the built environment in the name of 'public interest' through spatial policies and land management laws (e.g. New Towns Programme, Law 59 of the new urban communities management and its economic incentives) [31] [32] [38]. This is stated by Bayoumi as follows:

Figure (3) the incremental extensions of the built-up area of the NCS

Since the launch of the Open-Door and subsequent New Map of Egypt policies in April 1974, the Egyptian political economy has been divided into three distinct periods comprising: first, the transition towards freemarket economy or Open-Door policy era (1974 - 1987) [following the Arab-socialist era (1952 - 1974)]; second, dissolving public sector and the initiation of privatization (1987 - 1999) since the Economic Reform and Structure Adjustment Policy (ERSAP) was first introduced to Egypt in 1987; and third, the privatization and globalization era (2000 onwards).

The settlement was originally initialed by the Greater Cairo Region plan of 1983 as three residential settlements (i.e. settlements number 1, 3 and 5) to the east of the existing Cairo's urban agglomeration at the time. The Master plan of the NCS was formulated and approved in 1985 and since then it has gone through three master plan updates (i.e. 1995, 1999 and 2005) with an extensive allocation of land to high-income housing and gated communities, a noticeable shift in the target population (from 750,000 inhabitants to accommodated in 2010 in the original 1985 plan to 4 million inhabitants by 2027 in the 2005 updated plan), and a massive increase in the built-up areas: from 1800, 11270,21350 to 33620 hectares, respectively as shown in figure (3) [34] [35] [36] [37].

\subsection{THE 1985 NCS MASTER PLAN}

The master plan was formulated during the Open-Door policy era (1974-1987) seeking the smooth transition towards free-market economy after a long period of Arab-socialist policies (1952-1974). During the former era, on the one hand, the public sector was very active in widely spread infrastructure projects, including those of the New Towns Programme (NTP), and was recognised as the leading sector in constructing low and middleincome housing projects, carrying out many urban

\begin{abstract}
"This new town program was designated to be carried out and financed by the public fund. The state will carry out their vast majority of public and social subsidy housing districts, almost all the infrastructure and most of the public services and transportation facilities. Contrarily, the private sector was assigned to the industrial estates and some of the private residential neighborhoods and their local service" [30: 6]
\end{abstract}

The 1985 master plan was based on the objectives of the 1983 Greater Cairo Region (GCR) plan where three settlements (i.e. settlements number 1, 3 and 5) were located to east of the capital as shown in figure (3). The main planning vision is to accommodate the population overspills of the metropolis and to tackle the overgrown and spreading slums in the capital via encouraging the self-build household construction scheme in government-controlled planned settlements.

Consequently, each of the three settlements was planned to accommodate quarter million inhabitants with an area of 600 hectares, to be at least $3 \mathrm{~km}$ away from its nearest neighbour settlements, surrounded by a buffer area to limit its future expansion(s), and to be connected to the other settlements and the metropolis via tram links. It was planned to allocate $70 \%$ of the housing units of each settlement to the low and middle-income classes and $30 \%$ to the middle and upper middle-income classes while providing jobs for at least $4 \%$ of its labour force in planned industrial area located $2 \mathrm{~km}$ away from the settlement [39].

\subsection{THE 1995 NCS MASTER PLAN UPDATE}

During the rest of the 1970s till the mid 1980s, the new town program had siphoned almost all the public funds 
allocated for the urban development projects, either allocated devoted for establishing the new towns or for urban upgrading projects in existing cities. Moreover, the new towns surrounding the capital were unable to achieve their planning targets, with less than $4 \%$ of their target population in 1986, unable to relieve the metropolitan adverse urbanization problems, and unable to combat with the rigorous slums and to accommodate the overspills [40].

Driven by its massive $\$ 40$ billion foreign debt and pushed by the World Bank and other Egyptian creditors, in 1987, the Egyptian government unwillingly announced the adoption of the ERSAP in order to meet an IMF loan criteria, gain access to credits and to renegotiate its debts. Consequently, Egypt has compulsory embraced the World Bank's main economic strategies particularly those of the free market policies and the privatisation scheme [41].

Furthermore, in 1991, Egypt was even pushed further to apply the consequent ERSAP policies while using its role in the first Gulf War, as a tool in the bargaining process to abolish and/or reduce its foreign debts. Since then there has been four major changes in the political economy of Egypt that have direct impact on the formulation and implementation of all successive as well as existing national urban development policies and programmes. The four changes are emphasised by DiefAllah, Attia, Holt and Roe, and Sullivan as: the eradication of many poor and low income consumer subsidies, currency devaluation, privatization of most of the state assets especially its industrial firms, and the adverse reduction in public spending [32] [38] [42] [43].

Consequently, the private sector embraced the 1990s with a great deal of momentum; and since then its rising share in the national development process has been growing. Powerful individuals and interest groups expanded their control over the means of production and administration as their main representatives were incorporated into the ruling class [31].

In the light of the above political economy shift, there has been an update of the GCR plan in 1991, where the three original settlements have been merged to formulate the NCS that is known today targeting 4 million inhabitants in 2027. The new plan puts much emphasis on the private sector development as the government could no further support the New Towns programme on public funds. Consequently, the main aim of the New Towns programme, at the time, is to shift the urban development responsibility from the public to private sector by selling its land to local and foreign investors and to make as much revenue as possible to compensate the accumulated losses since the launch of the New Towns programme back in the 1970s [44].

In 1995, the first master plan update of the NCS was approved merging the three existing settlements (i.e. settlements number 1, 3 and 5) while adding further extension to the eastern boarder as seen in figure (3) and allocating almost all of its land to the construction of high-income gated communities, private villas and exclusive compounds. While Bayoumi evaluates the impact of the 1995 master plan update on the housing market for the poor and low-income class in the NCS, and stresses the following:

"Its planning concepts (of the
1995 NCR plan) were confirmed
its notion as residential dormitory
new town (...) changing its
housing policy to provide only
two types of land parcels; small
land parcels, each one has an area
of 600 m 2 devoted mainly for the
upper middle and high income
classes (...) In addition to the big
land parcels mainly large tracts of
land, each has an area from 10 to
500 hectares to establish gated
communities or residential
compounds for the elite and high
income classes. This anticipated
real estate changes accompanied
with the curtailing and limited
numbers of the public housing
flats for the middle and low
income has stimulated the process
of excluding the poor from its
housing market"
[30: 10 ]

Ever since the mid 1990s, "luxury and style" has been the slogan of the urban development in the NCS. Wherever you go, there are exclusive gated communities, private villas and compounds for the most profit luxury housing market; and story after story of multi-millionaires built their fortune of land speculations in the NCS benefiting from adopted indolent and nonstrictly development regulation to lure like those private investors.

\subsection{THE 1999 NCS MASTER PLAN UPDATE}

In 1997, the Greater Cairo Region (GCR) has undergone another major plan update bowing to the ever increasing pressure from private local and foreign investors on the central and local government to provide more land for investment. The pressure was certainly massive after the 1997 Luxor City incident, leaving the Egyptian economy in deep recession and pushing the government deeper and deeper into the mercy of the private sector [31] [32] [38]. Consequently, on the one hand, the private sector was at its full swing, control, and influence over the public policies decision-making process. On the other hand, the state continued to cut down on its welfare function while limiting its role to providing development projects (mainly social and urban projects) that support the regime to continue to govern (i.e. projects that help providing socio-political stability and control to keep the 
lid on social unrest) as predicted earlier by The Economist (1994) as follows:

"The government will implement
social policies to tackle poverty,
unemployment and infrastructure
shortcomings in order to combat
the Islamist threat and secure
domestic stability (...) this
include investing in basic services
and infrastructure in slum areas of
the main cities and putting extra
resources into education and
health" [45: 10-11]

The new city and urban planning aims were to promote the GCR competitiveness internationally and to achieve efficiency through minimal economic and physical/spatial intervention by state to support the market. Additionally, were to completely shift from state planning to a full swing private sector planning and management in order to promote investment growth and employment [31].

Consequently, in 1999 the NCS master plan underwent another update. This time, the sheer extension of the built-up area was massive (22670 hectares) nearly duplicating that of the 1995 master plan update, and equivalent to two third of the metropolitan built up area as seen in figure (2). On the one hand, almost all of extensions to the east ( 9600 hectare) have been allocated to high-income residential areas and its local services with very few zones allocated to the middle and uppermiddle classes. On the other hand, no land to be sold to low-income class and/or land for future low-income housing projects has been planned. Furthermore, a massive 13480 hectares were reserved for 'future urban development purposes' [36].

The urban development in the NCS since the approval of the 1999 update has become no more about social integration, community development, and social equity. It has become more and more about selling the city to whoever pays higher price, keeping the rich content and maximising the national revenues. Such new context and urban development environment alerted academics and practitioners questioning, 'Is it really worth the price communities are paying?'; while affirming the social and housing exclusion of the poor, the low and middleincome classes [24] [47] [48].

\subsection{THE 2005 NCS MASTER PLAN UPDATE}

In the early 2000s, given the situation of the shrinking public fund, the Egyptian government found itself obliged to aggressively integrate into the global economy by signing many agreements with overseas and transnational companies asking for extra large land parcels particularly in the newly developed areas within the GCR new towns as being one of the main hubs of economic and cultural affairs of the Egyptian and Arab countries [46]. This has been coupled with the signature of several international trade agreements (e.g. the Association Agreement with the EU, the lower trade barriers with the USA, the active application of the World Trade Organisation agreement, the signing of the Qualified Industrial Zones (QIZ) Agreement with the USA) and the issue of several investment and market simulation laws) [31].

This global penetration for the Egyptian political economy has begun to make its permanent marks and impacts on the urban landscape in the form of the evolving international language schools, international universities, luxury social and sport clubs, international hotels, entertainment resorts, luxury and golf course gated communities and exclusive residential compounds. Consequently, in 2001, the 1999 NCS master plan was re-visited mainly for infrastructure provision, while formulating an alternative land parcelling in the eastern extension. The new land parcels confirms the state intention to maximise revenue, where it varies from 40 to 150 hectares. The aim was to minimise the infrastructure budget by selling the land in big parcels for one or consortium of investors [44] [46].

In 2005, there has been a major cabinet shuffle that included the Minister of Housing, Utilities and New Urban Communities after being in power since 1993. There also has been the announcement of the presidential election manifesto that stresses the full unfaltering support to the private sector while committing the state to addressing the market imbalances and its effect on the poor and low-income classes.

Consequently, the NCS underwent another master plan update in 2005, based upon the announced presidential election manifesto. The new aim is to provide as much land as possible to the local and foreign investors while using the revenue in providing for the poor and lowincome classes. The master plan update was approved in 2007, adding some massive built-up area to the 1999 update reaching a total built-up area of 33620 hectares, 25000 hectares out of which allocated for the private sector development against 1800 hectares allocated for 'future development projects' targeting the poor and low-income classes, as shown in figure(2).

Since the year 2005 onwards, the whole urban development process in the NCS followed no rules and/or code of practice where $80 \%$ of land assets in the new settlements in GCR were sold in auctions to maximise revenues and profits; and where urban development policy and practice are heavily influenced and directed by investors and businessmen inside and outside the government. Bayoumi expresses the impact on the real estate market in the NCS as follows:
“in (1996) for only \$250,000 a homeowner can purchase a modest villa in the golf course gated communities and live among 500 hectares of artificial 
lakes and golf links, in (2007) he needs at least one million dollars to purchase the same villa, and at least $\$ 60,000$ to purchase a middle-income modest flat, which the vast majority of the metropolitan overspills can not afford (...) Due to their few number within the numerous ones located for the rich, the poor and low income districts seem to be stigmatic poor enclaves or pockets within the town's housing market"

[30: 8,11$]$

Over the coming section, the impact of the above presented successive urban development policies and its affiliate NCS master plan updates on the study population will be explored to document the various perceptions in order to highlight the magnitude of gains and losses the community experience in the NCS using the identified five key indicators for guidance.

\section{THE CURRENT CONTEXT: CLASH OF THE TITANS}

The research findings have been divided into five sections reflecting the five key-indicators presented in section 1. Most of the findings confirm deeper conflicts more than anticipated before the start of this research. It is even deeper, in my opinion, beyond any change of action or future urban policies can rewind. This has been evident in the word of two ex-top government officials directing the General organisation of Physical Planning (GOPP) in their presentation before the World Bank in April 2007. It confirms that it is happening not only in the NCS but also all over the new towns and settlements in the GCR, not to say all over Egypt [49]. In their presentation, they stress the impact of the successive urban development policies and plans on the GCR's new and existing towns and settlements as follows:

"complex institutional landscape complicates access to public land; lack of policy framework and market-based allocation mechanisms for public land; ineffective land use planning; and lack of information \& integrated database infrastructure (...) challenge is not about scarcity but distortions to the housing market caused by old policies that led in the past 4 decades to: a) a heavily subsidized public housing supply; b) a mismatch between supply and demand; and c) severe curtailing of private sector investment in housing supply" [49: 17]
If the above, among many others, is the documented professional opinion of top government officials directing the highest institution responsible for urban planning policies and practice in the country, then the conflict between parallel communities in the NCS was domed to happen. Paradoxically, it is happening under the nose of concerned government institutions and personnel. The question, whether they have been pushed to accept it or have been directing it all along to happen, is not the issue anymore. The issue is how to save local communities from self-destruction. Over the coming sub-sections, the paper depends heavily on quotes from the fieldwork just to highlight how far apart the neighbours are.

\section{A SENSE OF COMMUNITY: SOCIAL COHESION AND EXCLUSION}

The data collected under this category is divided into two groups: the sense of community from within gated communities and those within the NCS (i.e. between the residents of gated communities and the residents of the adjacent residential areas). On the one hand, the fieldwork revealed conflicting perceptions on the sense of community between residents of gated communities; however the majority of interviewees confirmed a stagnant and spontaneous rather than an active comprehensive sense of community. This has been summed up by one of the residents as follows:

\begin{abstract}
"We are all here because of our social status and class. Most of residents are stressing their status by the lifestyle and luxury you can see around you. You can say, the majority of residents know each other from the market and business relations (...) if you refer to a sense of community as those social relationships between neighbours and those we used to have in our villages and old districts of Cairo, just forget it (...) none of the residents have time to waste building the community relationships in this sense, where everyone here is a community in his own right"
\end{abstract}

On, the other hand, no sense of community between gated communities and adjacent residential areas could be documented. On the contrary, almost all of interviewees from all residents groups stress the complete blockage around the residents of gated communities, as explained by one of the adjacent residents as follows:
"they (the residents of Arabella) are the cream of the cream of Egypt man. What are you talking about; we can just dream of 
passing through their walls and gates not to mention entering their villas (...) what relations and which community, common, if you are lucky, a job in one of their companies is more than satisfying (...) why they would like to know us man. It is maybe an insult for them to even speak to us, God forbid"

To summarise, there is a great deal of evidence indicating social exclusion and segregation of the residents of gated communities as well as of the poor and low-income residential areas, where they become vivid urban enclaves. It has been also evident that social cohesion in the NCS is 'a living myth', where it does not exist either within the residents of gated communities and/or between communities from various income-class.

\section{SAFETY AND SECURITY}

The issue of safety and security touches on crime reduction, displacement of crime and response time [6]. Consequently, the collected data has been categorised to reflect the three issues above. First, with regards to crime reduction, it has been confirmed both by the residents and managers of gated communities as well as the local police that:

$$
\begin{aligned}
& \text { "the crime inside gated } \\
& \text { communities is very minimal and } \\
& \text { that the majority of gated } \\
& \text { communities within the NCS have } \\
& \text { recorded zero-crime since } \\
& \text { establishment" }
\end{aligned}
$$

Second, there has been a great deal of practical evidence to confirm displacement of crime in the NCS. Reports on crime, in the NCS, document theft of building materials, burglary of middle and high-income stand alone residences, and night street mugging. You can hear the voices of guarding dogs everywhere in the NCS at night. Not only residents are affected, the housing contractors have been also complaining as follows:

"when you see all those adds on TV and satellites about the NCS gated communities and luxury living style, you cannot stop feeling for the thieves (he laughed) (...) you cannot conduct business in the NCS without paying the a'rabs (desert gypsies) to guard your back at night. They are the guards as well as the thieves. They have been attracted to the NCS like us, just to ride the new wave of money harvesting since the mid 1990s. This, among many others, affects our budgets

and though the future residents are the receiving end of the increased unit price"

Finally, with regards to the response time of emergency services, there has been no practical evidence to support the connection between the locations of gated communities in the NCS and the response time of emergency services. One of NCDA employees explains as follows:

\begin{abstract}
"in case of a new planned zone, when land is sold to investors, instant adjustment of surrounding road network is carried out. On the other hand, when land is allocated to a specific investor within an existing planned zone (i.e. has a detailed land parcel plans); it is allocated with respect to the main surrounding road network. In this sense, it does not affect either traffic flow and/or emergency services"
\end{abstract}

\section{URBAN PLANNING}

\begin{abstract}
"what a complete chaos! What is happening in the NCS has nothing to do with urban planning as we (urban planning consultants and academics) know. It is rather a day-to-day real estate trading business (...) when you have no planning control over gated communities, weak urban management of high and middleincome residential districts, ongoing suspicious and fishy relationship between the NCSA employees and the public, and extreme lack of public spending and allocated fund for services, do not count much on urban planning practice"
\end{abstract}

The fieldwork also confirms a great deal of residents' resentment with respect to the performance of the NCDA. While residents and managers of gated communities perceive the NCDA as a weak entity that can be easily manipulated through class and business relationships, the high and middle-income residents are not convinced, it is there to manage the settlement affairs rather than just collecting money to maximise revenue by whatever means possible. Nevertheless, the poor and low-income residents still have faith in the NCDA. They perceive it as the source of power and control as expressed by one of the residents as follows:

"do you think a gated community
resident, manager and/or owner 
needs to deal with the NCDA. They do what they want over the phone or at most a dinner banquette. Other well off residents pay to have their needs done and pass anything through the mesh. What can we do, we have no connections or financial means, and hence we have to nearly beg for services"

While the NCDA [39] reports that $80 \%$ of public spending and funds allocated for services in the NCS was spent before 1999 , it states that $23 \%$ of sold out land parcels have been built till 2007, 63\% of which exceeded the maximum 5 years construction allowance period, while the remaining $77 \%$ are held for speculation purposes. It has also been reported that only $41 \%, 21 \%$, $15 \%$ of the anticipated public schools, health care centres and clinics, and youth centres, respectively, have been built to date accompanied with misdistribution of services resulted in depriving the most populated lowincome districts form service.

It has been revealed that the two newly-built public hospitals are still out of services due to the reluctance of the Ministry of Health to run such facilities in lesspriority less-populated settlement, to manage the scarcity of resources and to serve other crowded urban areas. Additionally, almost all of the poor and low-income interviewees expressed dissatisfaction with the existing poor and inconvenient public transportation and the irregular expensive private sector transportation services. The response over the public services issue was nicely put together by one of low-income residents as follows:

\begin{abstract}
"what you have in the NCS is a cash show off. If you have the cash and social status, you would live like a king in the NCS. However, if you have not, like me, you would see and live the other face of the coin. How many of us have the means to pay private school fees, private healthcare, social and sport club membership and/or can buy a car or even a motorcycle for transportation; and how many of us have secured employment? None of us, if you are still looking for an answer"
\end{abstract}

\section{URBAN GOVERNANCE AND MANAGEMENT}

Given the perception of the various study population on the role of the NCDA, presented above, there is enough evidence to question who is governing and managing what and whom? The evidence reveals that there is an outburst number of self-governed and self-managed gated communities in the NCS with respect to the dayto-day management and infrastructure supply and maintenance coupled with the lack of planning code enforcement.

There is also enough evidence to support the claim that the aim of the NCDA is to maximise revenue and minimise, if not abolish, public spending on services sacrificing community welfare. This was evident in the words of one of the interviewees as follows:

"urban governance is based on
urban democracy, where you have
everyone's voice taken into
consideration, which is not the
case here (...) you can govern
effectively and efficiently only
when you deliver and provide for
the community (...) but when you
have nothing or minimal
resources to spend on public
services and when you cannot
apply the very same planning and
administrative rules and
regulations to all societal groups
and social classes then urban
governance is a void slogan"

It has also been revealed that the NCS has a Board of Trustees (BOT), like all other new towns and settlements in Egypt, since the mid 1990s. The aim is to reflect the needs and requirements of all local groups armoured with sweeping powers over the decision-making process for the management of the settlement affairs. It has been revealed that the chairman of the BOT is a resident tycoon in one the gated communities (hand picked by the Minister of Housing) and the vice chairman is the head of the NCDA, a government employee. The rest of board members are appointed by the Minister of Housing via a ministerial decree, all of whom are handpicked and approved by the chairman of the BOT before leasing with the Minister in-person.

\section{ECONOMIC IMPLICATIONS: REAL ESTATE VALUE}

It has been revealed that the soaring number of gated communities, adopting the policy of selling and allocating land and properties via public auctions over the past five years, and a very active property speculation black market, have contributed dramatically to the unrealistic unjustified real estate values in the NCS. This is not only taking place with respect to gated communities and high-income properties but also to all income-based housing categories, keeping the poor and low-income groups at the boarders of the NCS and hammering the cash out of the 'late dreamers' searching for style and luxury. "The fashion bubble" has become the common term used by most of interviewees to 
describe what is happening in the NCS, where the market values do not reflect the actual values of properties.

The latter finding has been repeatedly confirmed during the interviews with all groups of the study population. The property market in the NCS has been caught in a vicious cycle. Unrealistic price of land (80-450 GBP/m2 in 2008), expensive construction materials (e.g. around 65 GBP per ton of cement and around 1000 GBP per ton of steel in 2007), unjustified labour wages and fees, leads to soaring prices of real estate residential properties at all levels.

Such unrealistic property values resulted in shifting the income-based social groups downwards on the property ladder. The high-income class can no longer afford buying properties in gated communities so they tend to buy land (550-800 $\mathrm{m} 2)$ and build their own villas, while the middle-income can no longer buy land but rather by ready built flats $(150-250 \mathrm{~m} 2)$. Additionally, the lowincome groups can no longer afford buying allocated flats by the government from original owners as the price becomes very high (17k - 35k GBP in 2009), and hence they tend either to rent or to buy properties allocated to the poor, who have no means to buy properties in NCS anymore. Finally, the poor, existing and newcomers search frantically, all over the NCS, to be employed as construction guards, porters and servants so they can have free accommodation.

\section{CONCLUSION}

This paper provides a brief documentation to the literature on the impact of gated communities on urban development and city management. It refers to the various research and projects concerned with the impact of gated communities on property value and city economy, city governance and management, security and lifestyle, the built environment and infrastructure and the social dimension of city development. Departing from the latter documentation, the paper focuses on five easyto-investigate indicators, reflecting the commonly agreed upon four underpinning elements of gated communities' development. The five key indicators: a sense of community - social cohesion and exclusion, safety and security, urban planning, urban governance and management, and economic implications - the real estate value, are the used to evaluate the gated communities in the New Cairo Settlement (NCS), Egypt.

After providing a brief background on the NCS, the paper links the successive urban planning of the NCS to the shifting political economy of Egypt since 1974 and consequently to the successive GCR plans. The research reveals that the transformation of the Egyptian political economy from socialism to the Egyptian version of capitalism since 1974, when the Open-Door Policy and it consequent New Egypt Map were launched, had a devastating impact on public policies in general and urban development policies and planning in GCR in specific. Consequently, the impact has been echoed on the formulation and implementation of the successive NCS plans since 1983. It is also revealed that the devastating impact become severe due to the forced adoption and application of the ERSAP since 1987 and later because of the change of laws and signature of various international agreements since 2000 .

Given the very basic pillars upon which the ERSAP was introduced to the World's economy with specific reference to the cut of public funds while maximizing government revenue, minimize state involvement and intervention in market processes, and to maximize the involvement of the private sector as the leading sector in national development in general and economic development in specific, the paper reveals that the social dimension of urban development in the NCS has been sacrificed. This has created an environment where there has been an outburst of exclusively luxurious highincome gated communities developed by the private sector, which controls the decision-making process of all aspect of development in the NCS via the BOT.

The paper reveals that the main reasons behind living in gated communities in the NCS are luxury, lifestyle and status. Consequently, it has revealed the lack of any sense of community whether inside the gated communities and/or between the gated communities' residents and the surrounding residential areas of all income-based classes. Additionally, the paper touches on the safety and security indicator where it has been revealed that crime within gated communities is minimal and no effect on response time of emergency services. On the contrary, there has been a displacement of crime to all other income-based residential areas.

Moreover, the paper also stresses that extreme lack of public spending and allocated funds for services since 1999 negatively affected urban planning policy and practice in the NCS. This has resulted in only $41 \%, 21 \%$, $15 \%$ of the planned public schools, health care centres and clinics, and youth centres, respectively, have been built to date accompanied with misdistribution of public services, depriving the most populated low-income neighbourhoods form public services. The latter, coupled with lack of urban democracy practice resulted in a vivid rift in community relations between the haves and have not. Consequently, parallel built environments and communities exist in the very same time and space edge resulting in deep rooted social conflicts and unrest.

Finally, the paper emphasises that the soaring number of gated communities, adopting the policy of selling and allocating land and properties via public auctions over the past five years, and a very active property speculation black market, have contributed dramatically to a 'bubble market' with unrealistic unjustified real estate values in the NCS. Consequently, there has been an evident downwards shift of the income-based social groups on the property ladder.

Whether Egypt has been forced to walk the walk of globalisation or has been heading frantically with a 
determined well towards it, does not matter at this stage. The paper goes beyond the reasons and causes and even beyond giving explanations of what is happening in the NCS. It alerts the decision-makers of a serious damage in community relations trying to curb the current course of actions to seriously avoid the 'clash of the titans'.

\section{REFERENCES}

1. Roitman S., 2008, "Urban Social Group Segregation: A Gated Community in Mendoza, Argentina", Unpublished $\mathrm{PhD}$ Thesis, Development Planning Unit, University College London, UK

2. Sanchez T., Lang R., and Dhavale D., 2005. "Security versus Status? A First Look at the Census's Gated Community Data", Journal of Planning Education and Research, 24(3), pp: 281-291

3. Atkinson R., Flint J., Blandy S., and Lister D., 2004, "Gated Communities in England: Final report of the Gated Communities in England", New Horizons project, University of Glasgow and Sheffield Hallam University, March 22, 2008, retrieved from www.odpm.gov.uk/stellent/groups/odpm_scien ce/documents/page/odpm_scien ce_024067.hcsp

4. Lentz S., 2006, More Gates, Less Community? Guarded Housing in Russia, in G. Glasze, C. Webster, and K. Frantz (Eds.), Private Cities. Global and local perspectives, Routledge, Oxon UK and New York, pp: 206-221

5. Parole - A Project Group, 2009, "Gated Community”, retrieved in October 2009, from http://parole.aporee.org/work/print.php?words_i $\mathrm{d}=356$

6. Landman K., 2000, "Gated Communities and Urban Sustainability: Taking a Closer Look at the Future", $2^{\text {nd }}$ Southern African Conference on Sustainable Development in the Built Environment: Strategies for a Sustainable Built Environment, 23-25 August 2000, Pretoria, South Africa

7. Webster C., Wu F. and Zhao Y., 2006, "China's Modern Gated Cities”, in G. Glasze, C. Webster, and K. Frantz, (Eds.), Private Cities. Global and local perspectives, Routledge, Oxon UK and New York, 153-169

8. Zaatar H., 2008, “Urban Vision", retrieved in October 2010, from http://www.businesstodayegypt.com/article.asp $\mathrm{x}$ ?ArticleID=7923

9. Zohny H., 2009, "Exiled in Suburbia”, AlAhram Weekly Online, January 29 - February 4, 2009, Issue 932, retrieved in March 2010, from

http://weekly.ahram.org.eg/2009/932/sc11.htm

10. ABC, 2009, "Background Briefing: Cairo: A Divided City", retrieved February 2009, on http://www.abc.net.au/rn/backgroundbriefing/st ories/2009/2477394.htm

11. Salama S., 2009, "Gated Communities”, AlAhram Weekly, retrieved May 2009, from http://weekly.ahram.org.eg/2007/857/op4.htm

12. Blakely E. and Snyder M., 1997, "Fortress America, Gated Communities in the United States", Brookings-Lincoln, Washington, USA

13. LaCour-Little M. and Malpezzi S., 2001, "Gated Communities and Property Values", Research Report, Madison, WI: Wells Fargo Home Mortgage and Department of Real Estate and Urban Land Economics - University of Wisconsin

14. PTI, 2008, "Gated Communities: A Hit in India”, Bangalore, August 24, 2008, retrieved in June 2010, from http://www.mydigitalfc.com/my-world/gatedcommunities-a-hit-india

15. Le Goix, Renaud LE GOIX Version, July 2003, "The Suburban Paradise or the Parcelling of Cities? -- An analysis of discourses, fears and facts about the sprawl of gated communities in Southern California”, retrieved in August 2010, from http://www.international.ucla.edu/article.asp?pa rentid $=4664$

16. MIVT, Metropolitan Institute at Virginia Tech, 2005, "A first look at the Census: Gated Community data examines the differences among different types of gated communities", February 23, 2005, retrieved in September 2009, from http://www.planetizen.com/node/15617

17. Shah S., 2006, "Motivation, Governance, and the Viability of Hybrid Forms in Open Source Software Development", Management Science, Vol. 52, No. 7, July 2006, pp. 1000-1014

18. Landman K., 2007, "Urban Transformation and Gated Communities: A Framework to Map the (Re-) Production of Urban Space and its Impact on Urban Governance in South Africa", International Conference on Private Urban Governance and Gated Communities, Paris - 58 June 2007

19. Pow C., 2007, "Public Intervention, Private Aspirations: Gated Communities' and the Role of the State in Singapore", International Conference Private Urban Governance and Gated Communities, Paris - 5-8 June 2007

20. Low S., 2004, "Behinds the Gates: Life, Security and the Pursuits of Happiness in Fortress America”, Routledge, London, UK 
21. Bjarnason S., 2000, "Lawn and Order: Gated Communities and Social Interaction in Dana Point”, Unpublished Ph. D. dissertation, University of Oregon, USA

22. Naude B., 2004, "An Evaluating of the Effectiveness of Gated Communities as a Tool in Dealing with Crime", Institute for Security Studies (ISS) Seminar, Pretoria: Gated Communities, 24 March 2004, retrieved in December 2009, from http://www.iss.co.za/pgcontent.php?UID=6728

23. Pinho P., Santos S., and Ferreira M., 2007, “The Impact of Closed Condominiums in the Form and structure of Metropolitan Areas", International Conference Private Urban Governance and Gated Communities, Paris - 58 June 2007

24. Ghonimi I., Alzamly H., Khairy M. and Soliman M., 2010, "Understanding and formulating gated communities inside Greater Cairo new towns urban fabric", $46^{\text {th }}$ ISOCARP Congress, 19-23 September 2010, Nairobi, Kenya

25. Zilli R. and De Titta A., 2007, "Leaving the city outside: Gated Communities in the urban region of Milan", International Conference Private Urban Governance and Gated Communities, Paris - 5-8 june 2007

26. Tshehla B., 2004, "An Overview of the Current Debate Regarding Gated Communities", Institute for Security Studies (ISS), 24 March 2004, retrieved in December 2009, from http://www.iss.co.za/pgcontent.php?UID $=6728$

27. Caldeira T., 2000, "City of Walls: Crime, Segregation, and Citizenship in Sao Paulo", CA: University of California Press, USA

28. Rahmaan A. and Anis B., 2009, "Dynamics of Gated Communities, Their Impact and Challenges for Sustainable Development: A Case Study of Lahore, Pakistan", Archnet-IJAR, Vol. 3, Issue 1: March 2009, pp: 57-70

29. Bayoumi W., 2010, “Greater Cairo New Towns 1977-2007: Obstacles and Mechanisms in the Voluntary Resettlement Process", Unpublished $\mathrm{PhD}$ Dissertation, University of Manchester, UK

30. Bayoumi W., 2009, "The Tale of the Unsettled New Cairo city- Egypt: A Review of the Implications of the Adopted Privatization and Laissez- faire Policy on Excluding the Poor from its Housing Market", Regional Studies Association Annual Conference, Understanding and Shaping Regions: Spatial, Social and Economic Futures, 6-8 April 2009, LevuenBelgium

31. Shetawy A., 2004, "The Politics of Physical Planning Practice: The case of the Industrial Areas in Tenth of Ramadan City, Egypt",
Unpublished $\mathrm{PhD}$ Dissertation, University College London, UK

32. Attia A., 1999, "Planning for Sustainable Development: An Investigation into Implementing Tourism Policy in the North West Coast Region of Egypt", Unpublished $\mathrm{PhD}$ Thesis, Development Planning Unit, University College London, UK.

33. Attia A., 2001, "Cities Spanning the Millennia: The Case of Cairo, Policies for Directing Urban Growth in Greater Cairo Region: A Critical Analysis", 6th World Congress of the Council on Tall Buildings and Urban Habitat, February, Melbourne Convention Centre, Australia.

34. NUCA, New Urban Communities Agency, 1986, "The Master Plans of the First, Third and Fifth Settlements", Final Report, Ministry of Housing, Report in Arabic, Report in Arabic

35. NUCA, New Urban Communities Agency, 1995, "New Cairo City: General Master Plan: Final Report", Ministry of Housing, Report in Arabic

36. NUCA, New Urban Communities Agency, 1999, "New Cairo City Eastern Extension Master Plan: Final Report”, Ministry of Housing, Report in Arabic

37. NUCA, New Urban Communities Agency, 2005, "Updating the General Master Plan of New Cairo City Final Report”, Ministry of Housing, Report in Arabic

38. Dief-Allah D., 2007, "Conservation Policies for Historic Areas and Cities in Egypt", Unpublished $\mathrm{PhD}$ Dissertation, Ain Shams University, Egypt

39. NCDA, New Cairo Development Authority, 2007, "the annual Enumeration of the Land Parcels Real Estate Market, Completed Housing Units and Public Services", Real Estate and Development Departments Achievement, Ministry of Housing, Annual Report in Arabic

40. Sutton K. and Fahmi W., 2001, “Cairo's Urban Growth and Strategic Master Plans in Light of Egypt's 1996 Census Results", Cities, No. 18, pp: $115-35$

41. Springborg R., 1989, “Mubarak's Egypt: Fragmentation OF the Political Order”, WestView Press, Boulder and London, UK

42. Holt R. and Roe T., 1993, "The Political Economy of Reform: Egypt in the 1980s", in R. Bates and A. Kreueger (Eds.), Political and Economic Interactions in Economic Policy Reform: Evidence from Eight Countries, Basil Blackwell, Cambridge

43. Sullivan D., 1990, "The Political Economy of Reform in Egypt", International Journal of Middle East Studies, No. 22, pp: 317-34 
44. Wahba M., 2002, “The Urban Geography of Low-Income Housing: Cairo (1947-96) Exemplifies a Model", the International Journal of Urban and Regional Research, No. 26, pp: 22-58

45. The Economist, 1994, "Country Forecast: Egypt", The Economist Intelligence Unit, 1st Quarter, London, UK

46. Kuppinger P. and College M., 2004, "Exclusive Greenery: New Gated Communities in Cairo", City and Society, No. 16, pp: 28-35

47. Stewart D., 1999, "Changing Cairo: the Political Economy of Urban Form", International Journal of Urban and Urban and Regional Research, No. 23, pp: 119-128

48. Stewart D., Yin Z., Bullard S. and Maclachlan J., 2004, "Assessing the Spatial Structure of Urban and Population Growth in the Greater Cairo Area, Egypt: A GIS and Imagery Analysis Approach", Urban Studies, No. 41, pp: 22-59

49. El Kouedi H. and Madbouly M., 2007, "Tackling the Shelter Challenge of Cities: Thinking it Through Together", The World Bank, April 30 